\title{
TM4SF1 Gene
}

National Cancer Institute

\section{Source}

National Cancer Institute. TM4SF1 Gene. NCI Thesaurus. Code C18607.

This gene plays a role in signal transduction events that are involved in cellular development, activation, growth and motility. 